\title{
Family planning and unmet need among Iraqi Kurds
}

S. Y. Agha' ${ }^{1}$ and B.O. Rasheed ${ }^{2}$

$$
\begin{aligned}
& \text { تنظيم الأسرة والاحتياجات غير الملباة للدى الأكراد العر اثيّيني } \\
& \text { سعل يونس أغا، بريغان عثمان رشيد }
\end{aligned}
$$

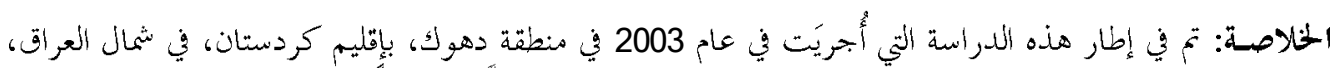

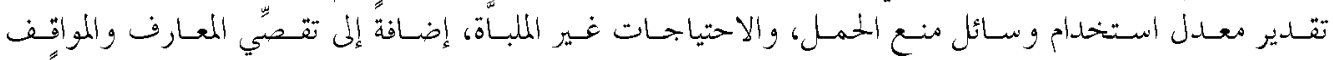

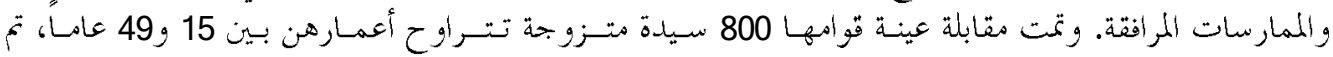

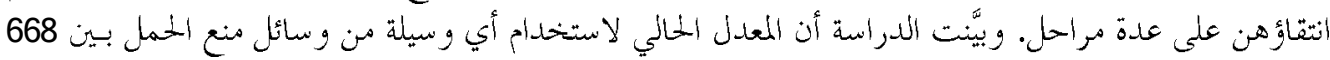

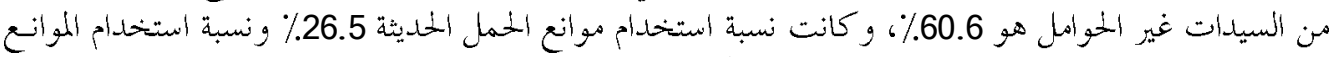

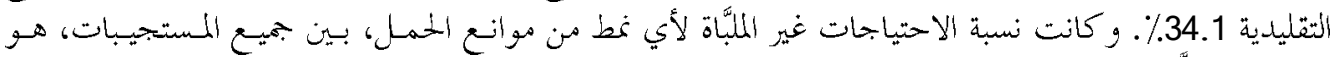

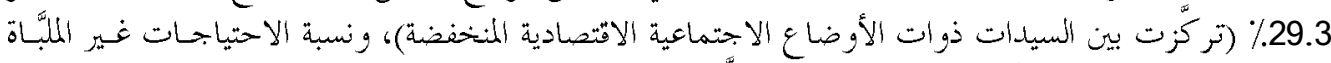

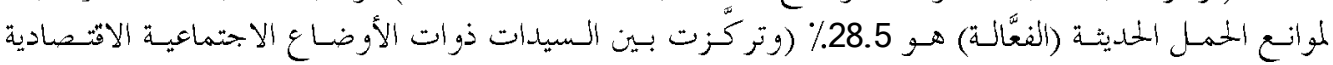

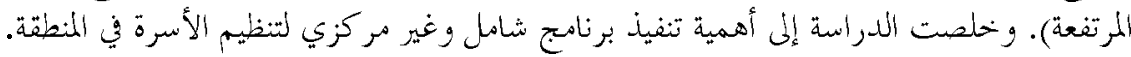

ABSTRACT This study in Dohuk district of Kurdistan region, northern Iraq, in 2003 estimated the prevalence of contraceptive use and unmet need, and investigated associated knowledge, attitudes and practices. With multi-stage sampling, 800 married women aged 15-49 years were interviewed. Current prevalence of contraceptive use (any method) among 668 non-pregnant women was $60.6 \%$ : use of modern methods was $26.5 \%$ and traditional methods was $34.1 \%$. Among all respondents, current unmet need for any contraception was $29.3 \%$ (most commonly among women of low socioeconomic status) and that for modern (effective) contraception was $28.5 \%$ (most commonly among women of high socioeconomic status). A comprehensive and decentralized family planning programme needs to be implemented in the region.

\section{La planification familiale et ses lacunes chez les Kurdes iraquiens}

RÉSUMÉ Cette étude menée en 2003 dans le district de Dohuk dans la région du Kurdistan au nord de l'Iraq avait pour objectifs d'évaluer la prévalence de l'utilisation de méthodes contraceptives et des besoins de contraception non satisfaits et d'analyser les connaissances, attitudes et pratiques en la matière. Recourant à la technique de l'échantillonnage à plusieurs degrés, l'enquête a porté sur 800 femmes mariées âgées de 15 à 49 ans. La prévalence effective de la contraception (toutes méthodes confondues) chez les 668 femmes non gestantes était de $60,6 \%$, avec $26,5 \%$ pour les méthodes modernes et $34,1 \%$ pour les méthodes traditionnelles. Sur l'ensemble des enquêtées, $29,3 \%$ - essentiellement des femmes socio-économiquement défavorisées - ont manifesté un besoin non satisfait de contraception, sans distinction de méthode, tandis que 28,5\% - appartenant majoritairement à un milieu socio-économique plus favorisé - exprimaient le besoin non satisfait d'une méthode contraceptive moderne, c'est-à-dire efficace. La mise en place d'un programme de planification familiale global et décentralisé s'impose dans cette région.

'Department of Public Health, College of Medicine, University of Dohuk, Dohuk, Iraq (Correspondence to S.Y. Agha: saadagha13@yahoo.com).

${ }^{2}$ Maternal Health Section, Department of Preventive Health, Directorate of Health, Dohuk, Iraq.

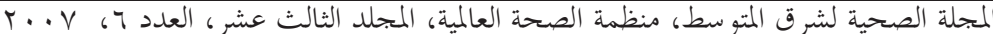




\section{Introduction}

Family planning implies the ability of individuals and couples to anticipate and attain their desired number of children through the spacing and timing of their births, achieved through the use of contraceptive methods and the treatment of involuntary infertility [1]. A planned family is the best environment for a child's overall development [2]. Large families and rapidly growing populations hold back development at both the household and national level [3]. High parity and close child spacing are related to increased maternal and childhood morbidity and mortality [4]. Worldwide, millions of women desire to have longer spaces between births or to limit the total number of births, but, especially in the developing world, they have unmet needs for contraception $[5,6]$.

Dohuk governorate is composed of 6 districts with a population of 850000 . It is currently one of the 3 main governorates comprising Kurdistan region in northern Iraq, and its centre, Dohuk district, is the 3rd large district in this region. Apart from private services, the current family planning programme in Dohuk governorate is limited to 2 government clinics; one opened in 1997 at the main general hospital in the centre of the governorate and the other opened in 2002 in Zakho district.

The aim of this study was to help inform the development of family planning services in the area by estimation of the prevalence of contraceptive use and of unmet need for contraception among currently married women aged 15-49 years in Dohuk district. The study included an investigation of the sociodemographic factors associated with unmet need and of knowledge, attitudes and practices (KAP) about family planning.

\section{Methods}

\section{Study area}

Dohuk district is a semi-mountainous area that is located in upper northern Iraq. Its population, about 350000 , are mostly Moslem Kurds, plus some other ethnic and religious minorities, living mainly in 28 urban areas (Dohuk city) and 9 periurban areas.

\section{Sample}

The current survey was conducted from 9 June 2003 to 30 September 2003.

A sample size of 800 currently married women in the reproductive ages of 15-49 years was estimated from: $\mathrm{N}=\left(\mathrm{PQZ} \mathrm{Z}^{2} \mathrm{D}\right) / \mathrm{E}^{2}$, where $\mathrm{N}=$ sample size, $\mathrm{P}=$ estimated prevalence of unmet need $=0.50, \mathrm{Q}=100-\mathrm{P}, \mathrm{Z}$ $=95 \%$ confidence level $=1.96, \mathrm{D}=$ design effect $=2, \mathrm{E}=$ accepted standard error $=$ 0.05 [7].

Multi-stage sampling was used. In stage 1, the 37 areas of Dohuk district were stratified into 4 socioeconomic strata: high $(n=$ $6)$, medium $(n=8)$, low $(n=14)$ and very low $(n=9)$, using a scoring system based on the type of building, sanitation, furniture and educational attainment (husband and wife) [8]. To facilitate sampling, this was done prior to the survey by visiting each area, all of them well-known to the authors. Areas within each stratum were randomly sequenced. In stage 2 the proportion of areas for each stratum was multiplied by the total sample size to obtain the number of women to be interviewed in that stratum. In stage 3 , areas were surveyed by random sequence, selecting every 5 th household until the required number of women for each stratum was achieved.

\section{Data collection}

Selected women were interviewed by a female doctor in their homes using a pre-

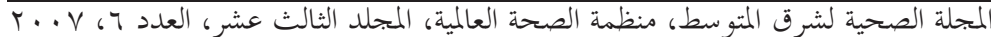


tested questionnaire designed for this family planning KAP survey. Probing was used to encourage mothers to answer sensitive questions. When an eligible woman was absent, the interviewer returned to her home later. The questionnaire form collected the following information about each woman:

- Personal particulars: socioeconomic stratum (as described above), age, marital age, educational attainment and employment outside the home, if any.

- Fertility experience: including gravidity, abortions, number of live births and deaths of children aged under 5 years.

- Family planning: all respondents were asked about their knowledge of the socioeconomic benefits of family planning, contraceptive methods and the main source of such information. They were asked if they ever used contraception and which type. Currently non-pregnant women were asked about any contraception they were using at the time of the survey, its type and source. Non-users were asked about the reasons for not using a contraceptive. Pregnant women were asked whether their pregnancy was planned, due to failure of contraception or due to non-use of contraception (unmet need). All respondents (except nulligravidas) were then asked about any history of successful or attempted induced abortion, and about their history of unwanted or mistimed pregnancies. All respondents were asked about their preferred family size.

The definition of current unmet need (point prevalence) was either: current nonuse of contraception when more children were not wanted, now or ever, usually with a statement of reasons for non-use; or current pregnancy due to non-use. This is the Demographic Health Survey (DHS) formulation of unmet need $[5,9,10]$ and in the current study it was regarded as unmet for any contraception. For countries with a high prevalence of traditional methods, an expanded formulation from the Johns Hopkins Reproductive Health Survey added traditional methods to the standard formulation [5], and in the current study this addition was regarded as unmet need for modern contraception. The sum of both types was regarded as all current unmet need for contraception. To estimate the size of the problem over the last 3 decades (period prevalence), any respondent who had current unmet need or gave a history of induced abortion or unwanted or mistimed pregnancy(ies) at any time during her reproductive life, was classified as ever having unmet need.

Continuous variables were categorized, ordinally when applicable, and described by frequency distributions. Associations of sociodemographic and KAP variables with current family planning use and unmet need were analysed by chi-squared tests using SPSS, version 12 . Yates' continuity correction was used in the case of $2 \times 2$ tables, and adjacent cells were combined as necessary in other cases.

\section{Results}

All the women selected for the study agreed to be interviewed, although $61(7.8 \%)$ needed a 2nd or 3rd visit.

Table 1 shows the characteristics of all respondents (pregnant and non-pregnant). About one-quarter of all respondents were living in periurban squatter areas and were classified as very low socioeconomic stratum. Nearly two thirds (62.4\%) of all women had married before the age of 20 years. The ages of more than two thirds $(71.8 \%)$ of respondents were between 20-40 years at the time of the survey. Half of the respondents were incapable of reading and writing. Two fifths of all women had at least 


\begin{tabular}{|c|c|c|c|c|c|}
\hline Characteristic & No. of women & $\%$ & Characteristic & Jo. of women & $\%$ \\
\hline Socioeconomic status & & & Total no. of live births & & \\
\hline Very low & 192 & 24.0 & 0 & 44 & 5.5 \\
\hline Low & 304 & 38.0 & $1-3$ & 300 & 37.5 \\
\hline Medium & 176 & 22.0 & $4-6$ & 224 & 28.0 \\
\hline High & 128 & 16.0 & $7-9$ & 144 & 18.0 \\
\hline Marital age (years) & & & $10+$ & 88 & 11.0 \\
\hline $12-15$ & 152 & 19.0 & No. of under-5 child deaths & & \\
\hline $16-19$ & 347 & 43.4 & 0 & 696 & 87.0 \\
\hline $20-23$ & 200 & 25.0 & 1 & 80 & 10.0 \\
\hline $24-40$ & 101 & 12.6 & $2+$ & 24 & 3.0 \\
\hline Present age (years) & & & Know benefits of family & & \\
\hline $10-19$ & 31 & 3.9 & planning & 659 & 82.4 \\
\hline $20-29$ & 292 & 36.5 & No. of methods known & & \\
\hline 30-39 & 282 & 35.3 & $1-3$ & 217 & 27.2 \\
\hline $40-49$ & 195 & 24.3 & $\geq 4$ & 582 & 72.8 \\
\hline Education & & & Source of information & & \\
\hline Illiterate & 427 & 53.4 & Health practitioners & 86 & 10.7 \\
\hline Primary school & 200 & 25.0 & Acquaintances & 680 & 85.0 \\
\hline Secondary school & 89 & 11.1 & Media & 34 & 4.3 \\
\hline Higher education & 84 & 10.5 & Ever attempted induction & & \\
\hline Employment & & & of abortion ${ }^{a}$ & 156 & 19.9 \\
\hline Not employed & 734 & 91.8 & Ever had unwanted & & \\
\hline Employed & 66 & 8.2 & pregnancy & 504 & 64.3 \\
\hline Total no. of abortions & & & Ever had mistimed & & \\
\hline 0 & 496 & 62.0 & pregnancy ${ }^{a}$ & 551 & 70.3 \\
\hline 1 & 280 & 35.0 & & 592 & 74.0 \\
\hline $2+$ & 24 & 3.0 & Ever-use of contraception & & \\
\hline
\end{tabular}

1 abortion, spontaneous or induced. About three fifths had 4 or more offspring and 13\% had experienced the death of a child aged under 5 years.

Knowledge about family planning and its benefits was very good as almost every respondent knew what family planning was, $82.4 \%$ knew some of its benefits and two thirds knew at least 4-6 methods. Most of the women $(85 \%)$ obtained their information from acquaintances; only $10.7 \%$ got information from health practitioners (Table 1). One fifth of respondents had a history of

(attempted) induced abortion, and around two thirds had experienced unwanted or mistimed pregnancy(ies). The median fertility preference for all respondents was 4 children.

Among pregnant women $(n=132)$, pregnancies were planned for 61 (46.2\%), due to failure of used contraception for $24(18.2 \%)$ and due to unmet need for contraception (non-use) for 47 (35.6\%). Three quarters (74.0\%) of all respondents had ever-used family planning in a similar pattern to that of non-pregnant women alone shown later.

المجلة الصحية لشرق المتوسط، منظمة الصحة العالمية، المجلد الثالث عشر، العدد ج، V... 
Table 2 shows current sources of family planning and reasons for non-use among the 668 non-pregnant women. Non-public sources, in form of private clinics and pharmacies, represented $73.8 \%$ of family planning services used by non-pregnant respondents. It also shows that about half of non-users stated the desire to have more children as the reason for non-use, while the other half stated reasons associated with unmet need.

Table 3 shows that among non-pregnant respondents $(n=668)$ current use of family planning by any method was $60.6 \% ; 26.5 \%$ were using modern methods and $34.1 \%$ were using traditional methods, namely withdrawal, lactation amenorrhea and periodic abstinence. Overall lower contraceptive use was associated with low socioeconomic and educational status, increasing maternal age and number of live-births and a history

Table 2 Current sources of family planning and reasons for non-use among nonpregnant women $(n=668)$

\begin{tabular}{lrr}
\hline Characteristic & $\begin{array}{c}\text { No. of } \\
\text { women }\end{array}$ & \% \\
\hline $\begin{array}{lrr}\text { Sources of family planning } \\
\text { service among users }\end{array}$ & & \\
$\quad$ Private clinics & 166 & 41.0 \\
$\quad$ Private pharmacies & 133 & 32.8 \\
$\quad$ Governmental clinic & 106 & 26.2 \\
$\quad$ Total & 405 & 100.0 \\
Reasons for not using & & \\
contraception & & \\
$\quad$ One or both partners want & & \\
$\quad$ more children & 126 & 47.9 \\
Religious beliefs & 70 & 26.6 \\
$\quad$ More than one reason & 37 & 14.1 \\
$\quad$ Mother-in-law objection & 19 & 7.2 \\
High price of contraception & 6 & 2.3 \\
$\quad$ Insufficient knowledge & 3 & 1.1 \\
$\quad$ Contraception not required & & \\
for medical reasons & 2 & 0.8 \\
$\quad$ Total & 263 & 100.0 \\
\hline
\end{tabular}

of death of a child aged under 5 years. Use of withdrawal and all traditional methods increased as the socioeconomic and educational standard improved. Female sterilization was most common among grand multiparas, particularly those who were illiterate.

Of all respondents, $80.8 \%$ ever had unmet need for contraception throughout their fertile life (period prevalence).

Table 4 shows that current unmet need for contraception was $29.3 \%$ by the standard DHS definition (unmet need for any contraception). However, another $28.5 \%$ also had current unmet need by the expanded Reproductive Health Survey formulation which adds traditional contraceptive users to the standard definition. This makes the total current unmet need $57.8 \%$. Table 4 also shows the distribution of all respondents by type of current unmet need according to important characteristics. Low socioeconomic and educational status, increasing maternal age and live births and a history of child death were all associated with high unmet need for any contraception and all current unmet need. Unmet need for modern contraception increased as the socioeconomic and educational standard improved and decreased with high fertility and a history of a child death.

\section{Discussion}

As in some other developing countries, people in Kurdish northern Iraq still value early marriage, large families and a role for woman inside the house. Additionally, the previous Iraqi government, particularly in the 1980 s, encouraged high fertility to compensate for human loss during its wars. Until the middle of the last decade, therefore, the Iraqi Ministry of Health neglected family planning in the country. This explains why Iraq's crude birth rate was among the 


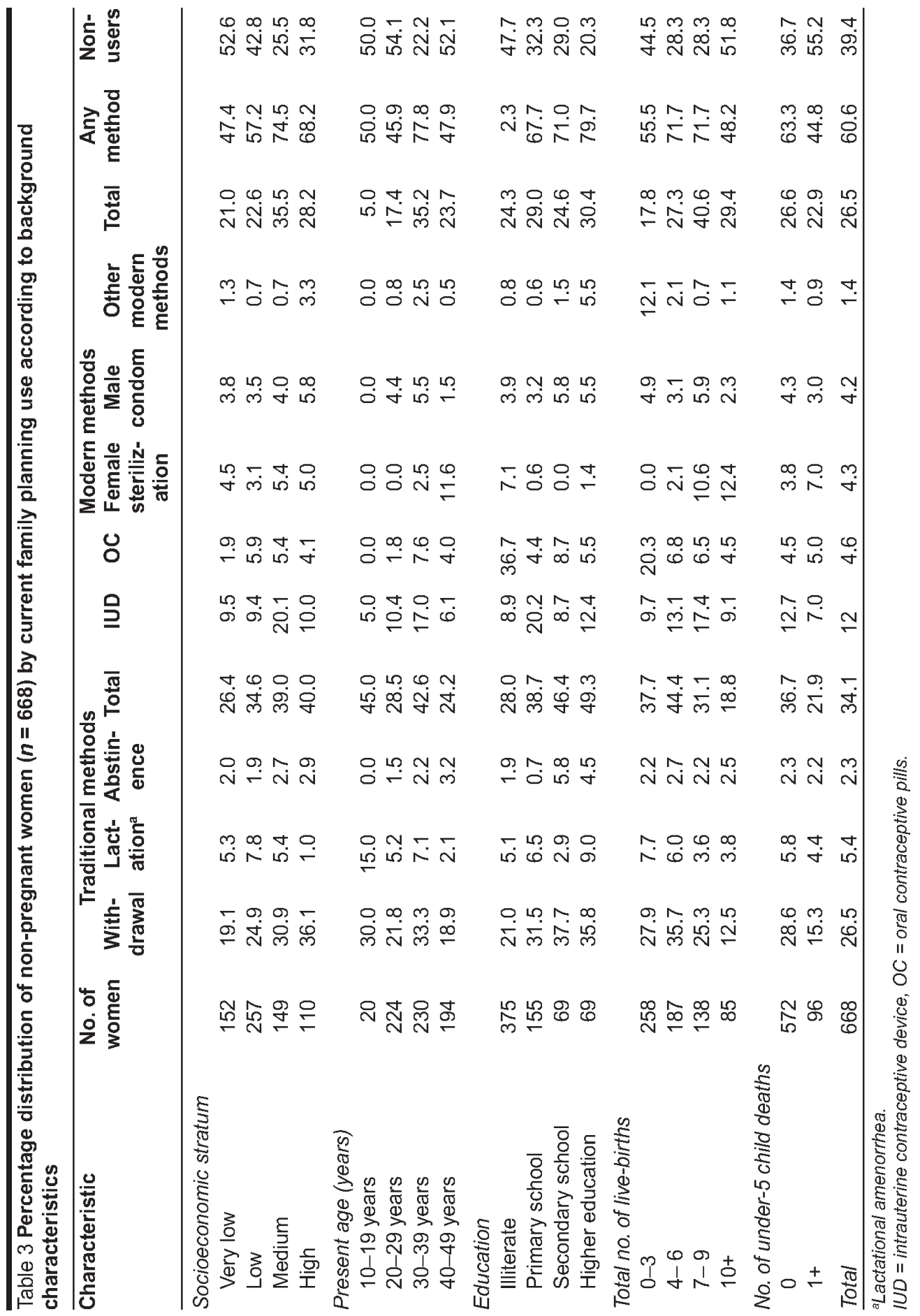

المجلة الصحية لشرق المتوسط، منظمة الصحة العالمية، المجلد الثالث عشر، العدد ج، V... 


\begin{tabular}{|c|c|c|c|c|c|}
\hline Characteristic & $\begin{array}{c}\text { No. of } \\
\text { women }\end{array}$ & $\begin{array}{l}\text { Unmet need } \\
\text { for any } \\
\text { contraception }\end{array}$ & $\begin{array}{l}\text { Unmet need } \\
\text { for modern } \\
\text { contraception }\end{array}$ & $\begin{array}{c}\text { All unmet } \\
\text { need }^{\mathrm{a}}\end{array}$ & Met need \\
\hline \multicolumn{6}{|c|}{ Socioeconomic stratum } \\
\hline Very low & 192 & 43.0 & 20.7 & 63.7 & 36.3 \\
\hline Low & 304 & 32.6 & 29.3 & 61.8 & 38.2 \\
\hline Medium & 176 & 18.2 & 33.0 & 51.2 & 48.9 \\
\hline High & 128 & 16.4 & 32.0 & 48.4 & 51.6 \\
\hline \multicolumn{6}{|l|}{ Present age (years) } \\
\hline $10-19$ & 31 & 29.0 & 29.0 & 58.1 & 41.9 \\
\hline $20-29$ & 292 & 28.7 & 26.3 & 55.0 & 45.0 \\
\hline $30-39$ & 282 & 19.5 & 34.0 & 53.5 & 46.5 \\
\hline $40-49$ & 195 & 44.6 & 23.6 & 68.2 & 31.8 \\
\hline \multicolumn{6}{|l|}{ Education } \\
\hline Illiterate & 427 & 38.6 & 24.3 & 62.9 & 37.1 \\
\hline Primary school & 200 & 26.0 & 29.5 & 55.5 & 44.5 \\
\hline Secondary school & 89 & 13.5 & 36.0 & 49.4 & 50.6 \\
\hline Higher education & 84 & 7.1 & 39.3 & 46.4 & 53.6 \\
\hline \multicolumn{6}{|l|}{ Total no. of live births } \\
\hline $0-3$ & 344 & 25.0 & 25.3 & 50.3 & 49.7 \\
\hline $4-6$ & 224 & 27.5 & 36.9 & 64.4 & 35.6 \\
\hline $7-9$ & 144 & 29.9 & 29.9 & 59.7 & 40.3 \\
\hline $10+$ & 88 & 50.6 & 17.2 & 67.8 & 32.2 \\
\hline \multicolumn{6}{|c|}{ No. of under- 5 child deaths } \\
\hline 0 & 696 & 26.6 & 29.8 & 56.4 & 43.6 \\
\hline $1+$ & 104 & 48.1 & 19.2 & 67.3 & 32.7 \\
\hline Total & 800 & 29.3 & 28.5 & 57.8 & 42.2 \\
\hline
\end{tabular}

highest in the world in the late 1980s and early 1990s [11]. At the time of the survey, health services in northern Iraq, including family planning, were almost free of charge at government clinics, when these were accessible, but expensive at private clinics and pharmacies.

The sociodemographic and fertility characteristics of our study population are consistent with the above. The notable features include high teenage marriage, high illiteracy and fertility rates and a very low employment rate of mothers. Knowledge about family planning was good, but information was mainly derived from acquaintances rather than from health practitioners.

For many mothers, sources of family planning services were private clinics and pharmacies, due to the limited and centralized nature of related public services. Apart from the desire to have more children, non-use of contraception among the studied population reflected local norms and religious beliefs.

Current use of modern contraception in this study $(26.5 \%)$ was low compared 
with countries such as the United States of America and Canada (70\%), Hungary $(68 \%)$, the Islamic Republic of Iran (56\%) and Egypt (53.9\%), but was higher than that for Yemen (9.8\%), Azerbaijan (11.9\%) and Sudan $(7 \%)[3,12]$. However, in the study population, more women were using traditional methods than in any other country in the Eastern Mediterranean Region [12]. Worldwide, levels of use of traditional contraception are generally much lower than that of modern methods [10], but a high prevalence of traditional contraception, in particular withdrawal, has been reported in neighbouring Turkey [13] and in Azerbaijan [10].

The high rate of female sterilization (tubectomy) among grand multiparas, especially illiterate women, is probably due to its being performed during caesarean section to deliver the last child. High rates of caesarean section have been reported in Iraq [14].

The relatively high rate of male condom use compared with neighbouring countries [12] may be due to availability of condoms free of charge, as for the intrauterine device and oral contraceptives, at the governmental family planning clinic in Dohuk. However, similar rates of male condom use have been reported for Iraq [14], Islamic Republic of Iran [12] and among Palestinian refugees [15].

A high prevalence of history of unintended (mistimed or unwanted) pregnancies and (attempted) induced abortion reflects the magnitude of the unmet need for contraception in this area over the past 3 decades. This is shown by a prevalence of ever-unmet need of $80.8 \%$. Unintended pregnancy, as an expression of unmet need, has always been a problem when women do not use contraception, or use traditional methods, for example in Egypt [16], Japan [17] and other developing countries [18]. Worldwide there are an estimated 87 million unintended pregnancies and 46 million induced abortions per year [19]. As abortion is generally illegal in Iraq, most induced abortions in this study were failed self-attempts, using heavy exercise or local herbs. However it is powerful evidence that women want to control their fertility when they have not been able to use effective contraception.

Current unmet need for contraception in the studied population by the standard DHS formulation (29.3\%), may be compared with countries such as Pakistan $(32 \%)$, Bangladesh (15\%), Egypt and Jordan (11\%) and Morocco (20\%) [10]. However, because many women were using traditional methods, the expanded RHS formulation was applied to give an estimated prevalence of all current unmet need of $57.8 \%$, and this would be higher than in any other region. Whether unmet need was for spacing or limiting births was not considered in this study, but based on the almost equal prevalence of history of unwanted and of mistimed pregnancy(ies), it may be assumed that an equal distribution of unmet need for spacing and for limiting births exists in the area.

Low socioeconomic and educational status, long fertile life, high parity and history of child death were associated with a high current unmet need for contraception (but not unmet need for modern contraception) in the present study as well as in other KAP and DHS studies locally, regionally and globally [20-23]. In particular, we can predict that mothers with a history of child death would be more likely to disregard family planning. Globally, DHS demonstrated this as a cause for continued high fertility in the less-developed countries [24].

In the current study the women with high socioeconomic and educational stratus had low unmet need for any contraception and all unmet need, but a high unmet need for modern contraception. Among this

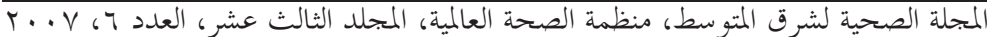


group, family planning use was high, but because of local traditions and difficulties with access to family planning services, they were relying on traditional contraception. Increasing rate of contraceptive use has been found to be accompanied, over time, by shifts toward use of more effective methods [25] and it is hoped this can occur among the studied population. Levels of unmet need have been found to rise as more and more women want to control their fertility and then fall as more and more women use contraception to do so [9]. That is why it is important to make modern contraception available to all couples.

It seems that in the study population, there has been a vicious cycle of low, or high but ineffective, contraceptive use resulting in many unwanted or mistimed pregnancies and even attempts at induced abortion. This unmet need for contraception leads to high use but ineffective family planning and high fertility. However, a sign of change in the study population is apparent from a fertility preference of 4 children. Average family size for all women, including many young mothers who have not yet completed their families, is in fact currently almost 4 , but for mothers above 40 years, average family size is almost double that.

\section{Conclusions and recommendations}

In the studied population, the women with low socioeconomic/educational status have high unmet need for any contraception; those with high socioeconomic/educational status had high unmet need for modern contraception. Both situations lead to high unwanted fertility. There is a need to provide comprehensive, accessible, clientsensitive and modern family planning services through all primary health care services in all districts of Dohuk. The community, in particular women's groups such as the Women's Union, should participate in planning (e.g. selecting the types of contraceptives to be made available), implementation (e.g. distributing contraceptives and educating the community in their use) and evaluating the services (e.g. by contributing to annual KAP surveys).

\section{References}

1. Family planning. Geneva, World Health Organization, 2006 (http://www.who.int/ topics/family_planning/en/, accessed 21 August 2007.

2. Health benefits of family planning. Geneva, World Health Organization, Division of Family Health, 1994 (WHO/ FHE/FPP/94.4).

3. State of world population 2002. People, poverty and possibilities. New York, United Nations Population Fund, 2002.

4. Safe motherhood: World Health Day information kit, 7 April 1998. Geneva, World Health Organization, 1998.
5. Robey B, Ross J, Bhushan I. Meeting unmet need: new strategies. Population reports, series J. Family planning programs, 1996, Sept.(43):1-35.

6. Ross JA, Winfrey W. Unmet need in the developing world and former USSR: an updated estimate. International family planning perspectives, 2002, 28:138-43.

7. Introduction to basic epidemiology and principles of statistics for tropical diseases control. Geneva, World Health Organization, 2002.

8. Nordenhäll C, Ramberg S. Exclusive breastfeeding in the Purworejo district, 
Central Java, Indonesia: The relationship between socioeconomic standard, knowledge about breastfeeding and prevalence of exclusive breastfeeding. Umeå, Sweden, Umeå University Department of Epidemiology and Public Health Sciences, 1997 (MSF reports, No 14).

9. Westoff CF, Bankole A. Unmet need: 1990-1994. Calverton, USA, Macro International, 1995 (DHS Comparative Studies No. 16).

10. Zlidar $V$ et al. New survey findings: the reproductive revolution continues. Population reports, 2003, Series M, No. 17:1-42.

11. Iraqi Family Planning Association: bibliography and history. Baghdad, Iraqi Family Planning Association, 2001.

12. World fertility report 2003. New York, Population Division, Department of Economic and Social Affairs, United Nations, 2003.

13. Goldberg HI, Toros A. The use of traditional methods of contraception among Turkish couples. Studies in family planning, 1994, 25:122-8.

14. Alwan A. Health in Iraq: a review of the current health situation. Baghdad, Ministry of Health, 2004.

15. Madi H. Contraceptive practices among Palestinian refugee women using the UNRWA MCH centre at Nuzha, Jordan. Eastern Mediterranean health journal, 1998, 4:27-35.

16. Youssef RM et al. Correlates of unintended pregnancy in Beheira governorate, Egypt. Eastern Mediterranean health journal, 2002, 8:521-36.
17. Goto A et al. Factors associated with unintended pregnancy in Yamagata, Japan. Social science and medicine, 2002, 54:1065-79.

18. Bongaarts J. Trends in unwanted childbearing in the developing world. Studies in family planning, 1997, 18:267-77.

19. World health report 2005. Make every mother and child count. Geneva, World Health Organization, 2005.

20. Fadhel NN. Knowledge, attitude and practice of contraceptive methods among Iraqi women [DPH dissertation]. Mosul, Iraq College of Medicine, 2003.

21. Mohammad HQ. KAP study on reproductive health among adolescents and youth in Assiut governorate, Egypt. Cairo, Egypt, National Population Council, 1998.

22. Al-Nahedh NNA. The effect of sociodemographic variables on child spacing in rural Saudi Arabia. Eastern Mediterranean health journal, 1999, 5:136-40.

23. Castro MT. Women's education and fertility: results from 26 Demographic and Health Surveys. Studies in family planning, 1995, 26:187-202.

24. Strawn LMG, Stupp PW, Mei Z. Effect of a child's death on birth spacing. In: Montgomery MR, Cohen B, Eds. From death to birth: mortality decline and reproductive change. Washington DC, National Academy Press, 1998:39-73.

25. US Census Bureau. Global population profile: 2002. Washington DC, US Government Printing Office, 2004 (International Population Reports WP/02). 